\begin{tabular}{l} 
RCCS \\
\hline Annual Review
\end{tabular}

\section{RCCS Annual Review}

A selection from the Portuguese journal Revista Crítica de Ciências Sociais

$2 \mid 2010$

Issue no. 2

\title{
From the Expansion of the Market to the Metamorphosis of Popular Economies
}

\section{Pedro Hespanha}

Translator. Sheena Caldwell

\section{CpenEdition}

\section{Journals}

Electronic version

URL: http://journals.openedition.org/rccsar/210

DOI: $10.4000 /$ rccsar. 210

ISSN: 1647-3175

Publisher

Centro de Estudos Sociais da Universidade de Coimbra

\section{ELECTRONIC REFERENCE}

Pedro Hespanha, « From the Expansion of the Market to the Metamorphosis of Popular Economies », RCCS Annual Review [Online], 2 | 2010, Online since 01 October 2010, connection on 23 April 2019. URL : http://journals.openedition.org/rccsar/210 ; DOI : $10.4000 /$ rccsar. 210 


\title{
Pedro Hespanha
}

School of Economics and Centre for Social Studies, University of Coimbra, Portugal

\section{From the Expansion of the Market to the Metamorphosis of Popular Economies ${ }^{*}$}

\begin{abstract}
Recognising the existence, in this context of crisis, of widespread dissatisfaction with an economic and social system which is blind to social inequalities, insensitive to the social effects of unbridled competition, and complacent as regards the depredations wrought on nonrenewable resources, this article reflects on the persistence of economic forms differing from the capitalist system, which exist alongside it, as well as on the emergence of social movements and practices of resistance to the logic of this system, as is the case of the solidarity economy. The article goes on to ponder how these forms can serve as a basis for a far-reaching paradigm change, and thus contribute to a fairer system, better equipped to match resources to needs and maximise human and social well-being.
\end{abstract}

Keywords: Popular economy; solidarity economy; economic rationality; economic sociology.

\section{The capitalist economy and other economies}

There is widespread and increasing dissatisfaction with the capitalist economic system, in particular in its neoliberal form, for a great variety of reasons: its blindness to social inequality, its insidious and excluding globalisation through international production chains, the relocation of employment on a global scale, its insensitivity to the "processes of creative destruction" which exhaust resources prematurely, the social costs of the deregulation of labour, the squandering of non-renewable resources, the creation of artificial needs, and ultimately the "corrosion of character" of the economic agents themselves. This dissatisfaction often gives rise to a search for alternative solutions, revaluing economic practices based on principles other than competition and profit and envisaging a society in which the radical separation between the economic and the social might be replaced by ways of adjusting resources to needs in an integrated manner capable of maximising human and social well-being.

In order to think differently, it is necessary to begin by relativising the dominant economic theory, its presuppositions and its limitations, deconstructing its image as the only possible explanation for materially based social relations. This is achieved, from the outset, by interrogating the legitimacy of the object of economics - economic phenomena or facts separated from other aspects of social life.

\footnotetext{
* Article published in RCCS 84 (March 2009).
} 
Societies live and reproduce themselves through very complex and different relations that can only be compartmentalised by the academic disciplines through abstraction and simplification. They are complex relations in the sense that within them ethical and religious aspects are combined with political aspects (power inequalities, processes of domination), sociological aspects (social structuration, social differentiation) and economic aspects (the production, exchange and distribution of goods and services).

An object is "disciplined" whenever an area of knowledge wishes to impose a particular view of social phenomena and social relations and generalises it to include the entire field. The efforts of Gary Becker's rational choice theory to impose itself on other fields within the social sciences such as government, affective relationships, family life or education, without making any distinction between what is rational and what is social in human actions, has been termed economic imperialism by Kenneth Boulding (Boulding and Tapan, 1972).

The official "science of economics" (conventional, orthodox, institutionalised, dominant, neoclassical), therefore, presents itself today as the only legitimate means of understanding the phenomena and relations we designate as economic, and claims that the other sciences that have emerged to dispute its object are only capable of explaining certain particularities that escape the interpretative model of economics, without calling it into question. It is as if there were a legitimate division of academic labour in which the economists concentrate on the elementary functions of production and consumption, leaving the other cultural dimensions of human behaviour (i.e., the moral, ethical, religious, political dimensions, etc.) to the remaining social sciences.

However, this stance would clearly appear to be illegitimate at present. Firstly, within economic theory other views of the economy also exist which diverge radically from the neoclassical model. This is the case, for example, with the institutionalist trends which recognise that perfect calculation, self-contained rationality and pure cognitive models do not exist. The economy is impure in the sense that its logic is limited by the "institutions, ways of thinking and acting that people create to face the uncertain and the unexpected" (Reis, 2007). Secondly, the contribution made by other disciplines towards understanding the phenomena of social life (the economy as a "living process") is not residual or merely instrumental to the models conceived of by official economics (Cattani et al., 2008). On the contrary, the reductionism of these models - which translates, for example, into considering any behaviour that is different from the typical behaviour of homo oeconomicus 
to be "irrational" or "perverse", such as the observations of Gregory King in the $17^{\text {th }}$ century on the elasticity of supply and demand amongst the peasantry, or the masking of the limitations of the knowledge produced by econometric models that resort to the ceteris paribus assumption - has been compensated for by the decisive theoretical contributions of other disciplines.

Karl Polanyi has provided the best formulation of the problems that emerge when we fail to take into account the processes involved in the consolidation of capitalism as the dominant economic system and its links to the modes of production, transformation and exchange that it came to dominate (Polanyi, 1944). In distinguishing four principles of economic behaviour revealing different rationales - householding, reciprocity, redistribution and the market - Polanyi helps us to understand the plurality of economic forms over time and in the present day. As he explains, history and ethnography have experienced various kinds of economies.

Close observation enables us to recognise the co-existence of at least three forms of economy in contemporary societies: the mercantile or market economy, the non-market redistribution economy (run by the state) and the non-monetary economy, based on simple local exchange and reciprocity. We may argue about the role played by these different forms in the reproduction of market capitalism and accept that capitalism has a very powerful inclusive capacity that enables it to incorporate non-standard systems, but it can hardly be said that these do not contain risks for capitalism, that they cannot transform themselves, under certain conditions, into factors of resistance and contradiction that diminish their role in reproducing capital.

Many studies on peasant farming communities show that an economic system that was never dominant in any way may survive for centuries and maintain its essential rationale: the broad-based survival of families living in a community through careful management of resources and a solidarity generated by shared threats. A kind of moral economy, based on customs and past experiences, functions as a protective shell and reduces the disintegrating impact of the dominant economic system, whether feudalism, capitalism or actual socialism (Lipton, 1968; Tepicht, 1973; Scott, 1976; Popkin, 1979).

The disintegration of social relations based on reciprocity and mutual self-help never was complete, and therefore the peasant systems have experienced a process of change, yet have resisted. What can be seen in them may be extended, with no major changes, to other 
forms of popular economy that share the same locally-based sociability, reinforced by shared knowledge, the transparency of roles, and trust, expressed in collective actions of a popular nature. It is true that the weapons of the dominant system are very powerful and include a significant measure of manipulative ideological processes. In the case of capitalism, the incentive towards societal individualism (being a free-rider) or possessive individualism (being an owner), the devaluing of interpersonal trust ("never mix business and friendship"), the instigation of the unrestricted consumption of material goods as means of achieving personal happiness, are all tools used to domesticate alterity and homogenise behaviour under the aegis of a market logic.

Faced with this scenario of contradictory forces, the question of the relative autonomy of non-capitalist economies is an open one, subject to empirical proof. The persistence or emergence of social movements and practices resisting the logic of the capitalist system of today, as is the case with initiatives within the solidarity economy (in particular the more organised ones), do not escape the risk of being made invisible and becoming "wasted experience", but nevertheless may serve as the basis of a profound paradigm change, undermining the conditions for the reproduction of the capitalist market system. We do not know if processes such as the solidarity economy, which establish themselves as alternatives to the standard economy, are capable of unleashing a transformation in society, but the fact is that such processes cannot be silenced or wasted.

\section{Trajectories of the popular economies}

We know how, in order to establish and consolidate itself, capitalism had to destroy or subvert the economies that preceded it. This process took centuries and was marked by events that dramatically changed the lives of individuals and the communities in which they lived, attacking the bases of their economic reproduction, including

- the expulsion of peasants from their land by the enclosure laws in England, remembered by Marx in Vol. 1 of Capital;

- the proletarianisation of the expelled peasant families and their wretched working conditions in English cities during the industrial revolution, described by Engels in The Condition of the Working Class in England and by Charles Dickens in Hard Times; 
- the control over the autonomy and the gradual submission of artisan labour to capital, as exposed in the unpublished chapter of Capital and praised by Adam Smith in The Wealth of Nations;

- the gradual privatisation of communal goods which were the basis of the survival of peasant communities, well documented, in the case of Portugal, in the work of Albert Silbert (1978);

- the destructuring of local economies due to the expansion of capital markets, a process clearly evident in the Memórias Económicas da Academia das Ciências de Lisboa at the end of the 18th century that has continued uninterrupted up to the present day, with periods of particular intensity, such as European integration or the imposition of structural adjustments on developing economies resorting to aid from the World Bank or the IMF.

This process of change did not take place without encountering resistance and conflict, the memory of which has also been preserved. There were the countless peasant revolts from the dawn of capitalism to the present day, the struggles of the workers' movement since the $19^{\text {th }}$ century for better working conditions and pay, the anarchist movement against the state and the institutions that stifle freedom and control ways of life, the leftwing democratic or socialist thinkers who have questioned the political legitimacy of governments and institutions that promote capital, inspiring the formation of parties with the same ideology, and the cooperative and mutualist movement, working class in origin, which broke the stranglehold of the entrepreneurial organisation of labour and encouraged the weaker sectors of society to form associations to provide for their own needs.

In destroying and subordinating anything that was alien to it, this developing hegemony of the capitalist economy raises an important question which I would like to deal with in the second part of this paper: the vitality and autonomy of the forms that present themselves today as alternatives. I do not intend to approach this question systematically and exhaustively, scrutinising the processes of resistance and transformation of pre-capitalist economies, listing the factors involved in their disintegration or resilience, redefining the limits of their autonomy vis-à-vis the capitalist market rationale or distinguishing what is still alternative in them. I intend to limit myself to reflecting on the trajectories of change in the forms that have most resisted capital, which I will broadly term the popular economies, thus 
including peasant and working class situations, local economies, artisan and small family production, and popular economic skills.

With regard to this universe, I aim to show that trajectories are based on two main strategies: the first involves the adaptation of the actors to the capitalist market system, using the position held in the popular economy or informal economy as a resource, whilst in the second the actors maintain their position in the popular economy, using the market and the informal economy as a resource. What these strategies have in common is the fact that the actors are playing two games simultaneously, assuming hybrid (if not contradictory) behaviour, and are subject to processes of identity reconfiguration. In either case, the results do not always correspond to the planned strategies or else denote an alteration in strategy as changes unfold. It is therefore relevant to add a third trajectory, which may lead either to the return of the agents to the status of an alternative to the capitalist model or to the conversion of their popular economy into capitalism.

The empirical evidence on which my reflections are based is the result of studies conducted in Portugal, either by myself or in which I have been involved, and includes past studies of peasant communities and small-scale production, and more recent studies on unemployment, precarious employment and micro entrepreneurialism (Hespanha, 1990, 2000; Hespanha et al., 1990, 2002a, 2002b, 2007; Sousa et al., 2007; Portela et al., 2008).

I will begin by analysing the economics of these micro-entrepreneurs in order to emphasise the fact that two previously mentioned strategies can be found among them and that, during the course of creating a business or a company, the strategic orientation may change. Some implications of this fact, which I anticipate already as a conclusion, are that the micro-entrepreneur is not automatically a potential capitalist (he may be a maximiser of well-being but not necessarily a maximiser of profit), that it is very difficult to rise from being a micro-entrepreneur to a major entrepreneur (as the market is implacable towards entrepreneurs who do not maximise profit), that a small business is almost always the result of the cooperation of many people, and that the experience of someone who has put together a business may be extremely useful for a collective venture based on solidarity.

Following this, I will focus on small informal business activities as a base for more established enterprises and, finally, will discuss the collective forms of microentrepreneurialism guided by the aims of cooperation and solidarity. 


\subsection{The economics of micro-enterprises}

Micro-enterprises or small businesses are particularly widespread in societies in which small-scale production proliferates, with few links to the market, driven by a non-profit based rationale and developed by people with limited resources, as is the case in Portugal and in the majority of southern European societies. It is enough to note the high levels of self-employed business activities in these countries (Portugal, 21\%; Spain, 19\%; Italy, 29\%; Greece, $32 \%$, as opposed to $16 \%$ in the UE25) ${ }^{1}$ and the preference for self-employed status (Portugal, 62\%; Spain, 56\%; Italy, 55\%; Greece, 52\%, as opposed to $45 \%$ in the UE15) ${ }^{2}$ to deduce that we are looking at situations that do not correspond to the ideal business model.

Official statistics usually designate micro-enterprises as businesses which employ up to 10 people. In 2005, they represented $92 \%$ of the total number of companies in the EU, employing $30 \%$ of the workforce and corresponding to $21 \%$ of total added value. In Portugal, there is an even greater number of micro-enterprises in the non-financial sector, representing $93 \%$ of the total number of companies, corresponding to $42.7 \%$ of the total number of employed workers and $30.6 \%$ of the added value.

According to the same source, the average number of employees per micro-enterprise was 1.7 people, and the proportion of businesses run by only one person was particularly high in certain areas (transport and communications: 64.2\%; hotel and catering: 64.6\%; trade and repairs: 73.8\%; and real estate: 85.4\%). Companies with up to 4 employees represented $79 \%$ of the total for micro-enterprises in the combined business areas.

When these companies and their entrepreneurs are analysed, the most obvious aspect that emerges is that they do not share all the attributes of the typical business model for entrepreneurialism recognised by standard economic theory, that is, the creation of value (Say, 1821), innovation and change (Schumpeter, 1934), the search for opportunity (Drucker, 1985) and confident management, envisaging and assuming risk or uncertainty (Knight, 1921). In fact, many of the businesses created by single individuals or small collectives do not obey all the theoretical requirements: either they do not create value since they are based in traditional areas of business, or else do not represent any innovation in terms of management and product, or do not result from any ability to seek out

\footnotetext{
${ }^{1}$ Eurostat, "SMEs and Entrepreneurship in the EU", Statistics in Focus - Industry, Trade and Services (24/2006); and "Key Figures on European Business 2006", Statistical Pocketbook.

${ }^{2}$ EC, Flash Eurobarometer: Entrepreneurship (June 2004).
} 
opportunities but are instead an option induced or chosen as an alternative to another less viable one, such as working for someone else, or, finally, they do not display any confidence on the part of the entrepreneur, who appears very attached to a cautious, routine style of management.

The decision to create a company - the choice of self-employment rather than working for others - may result from one of two kinds of economic drives: either the drive to take advantage of a business opportunity or the pressing need for an income which cannot be obtained in any other way. Hence the classic distinction between opportunistic entrepreneurship - in the sense proposed by Schumpeter (1934), which includes individuals with entrepreneurial abilities who detect a potentially lucrative business opportunity, and have a greater understanding of technologies and/or markets, greater management skills, less aversion to risk, or other personal characteristics which makes them more attracted to the idea of self-employment - and necessity entrepreneurship, including individuals who, in the absence of opportunities to work for others or, at least, jobs suited to their specific skills, opt for self-employment not because they have discovered a business opportunity but due to a lack of more favourable alternatives for their survival. In the latter case, the individual is pushed towards self-employment, seeing it as a refuge from unfavourable conditions in the employment market.

A study conducted in Portugal (Portela et al., 2008) found that, at the outset, the situation of micro-entrepreneurs was very different with regard to employment status, and the idea of creating a business was therefore based on diverse motives. From the point of view of employment status, when the idea of a business presented itself, the microentrepreneurs in the study fell into different categories: unemployed in search of a new job, unemployed in search of a first job, salaried workers, workers in family businesses and selfemployed individuals.

Within the category of the unemployed in search of a new job, it was possible to distinguish situations in which individuals had lost a job without wanting to, and others in which they had voluntarily left the job they had. In the first case, self-employment was considered either as the last resort in the face of the lack of salaried work, or as an opportunity to a desire to work for oneself, given that a reasonable proportion of the necessary conditions could be met (e.g. having experience as well as professional qualifications, a network of "contacts", the opportunity to resort to institutional financial 
support, etc.). In the second case, the voluntary abandonment of work corresponded to motives that were also very specific, such as reconciling working life with caring for children, escaping from a precarious employment and/or moral harassment in the workplace or the search for an independent working life and therefore a greater level of satisfaction. From the point of view of motivation, in both cases either the presence of the previously defined necessity entrepreneurship or opportunistic entrepreneurship may be detected.

In the case of the unemployed seeking their first job, the main concern was to find, "grab" and hold onto an alternative to the lack of salaried work, clearly showing the presence of necessity entrepreneurship. Amongst the micro-entrepreneurs who had been salaried workers, the situation of those who created a business with the aim of getting out of this situation was clearly different from that of those who created a business without this intention, and were seeking to combine both conditions. In the first case, the motives were to find greater work satisfaction and to recognise that they had the necessary abilities to "fight" for self-employment, but also to find a business "opportunity" and to recognise that the conditions were in place to put it into practice (e.g. experience and professional qualifications, a network of "contacts", own financial resources, the possibility of obtaining a bank loan, etc.). In other words, the motivation had as much to do with necessity as with business opportunity. In the second situation, the concern to combine the status of employee with that of entrepreneur resulted, in one case, from a solidarity-based motive (accepting an invitation to lead a cooperative of female craft workers in order to help them and, at the same time, contribute towards development in the region), whilst in another case it was the desire for more income in addition to the amount earned from salaried employment and, in a third case, the desire to put an old business idea into practice without abandoning the career the person had been building as a salaried worker. The latter case denotes a clear choice of opportunistic entrepreneurship.

There were also situations in which micro-entrepreneurs were already working in family businesses or in their own businesses. In the first situation, the creation of a new business corresponded to the desire or the need for independence from the family, coinciding with starting one's own family, or even a firm desire for personal autonomy. Once again, the different cases show that motivation oscillates between adverse integration and business opportunity. In the second situation or, in other words, when it was a matter of creating a 
new business after previously running one, the motive may be expansion into another area of work (e.g. a freelance masseuse who wants to sell natural products and therefore opens a herbalist's store), expansion to include a complementary activity, due to the success of the former (producing what was formerly only sold, or selling what was previously produced only for self consumption), taking one more step forward in a successful trajectory (e.g. closing a take-away establishment to open a restaurant in larger premises), continuing to do what one enjoys on an independent basis, or even looking for a new challenge when the former business no longer offers personal fulfilment. In any of these cases the motivations correspond to a desire to grow by taking advantage of opportunities. However, there are also rival motivations, such as setting up the business in separate premises in order to improve working conditions or enjoy greater autonomy by leaving a previous business after misunderstandings with partners. In these cases the change does not correspond to an impulse towards entrepreneurship, but to a means of solving previous work-related problems.

In general, from amongst the 70 cases of micro-entrepreneurialism studied, there is a balance between situations based on necessity and those based on opportunity, although we are aware that it is not always easy to classify motives. This is sufficient for us to conclude that the diversity of microenterprises clashes with the prevailing concept of the entrepreneur and entrepreneurship, and that the variant of necessity entrepreneurship would find it hard to pass the test for the attributes required by this concept.

We may, however, take things further and see in these differences not only a question of motivation but, above all, a question of economic rationale. To simplify once again, our assumption is that some small businesses are part of an economic logic that is typical of the domestic economy, the popular economy or direct small-scale production which are based on the principle of maximising well-being and the economic reproduction of the group instead of maximising profit, as the capitalist market rationale does. There are many indicators which favour this hypothesis in the cases studied: recourse to paid or unpaid work outside the family using primary solidarity-based networks; the total or partial informality of market relations, relations with institutions and relations with the community; the relative lack of distinction between the domestic economy and the entrepreneurial economy; a retreat into self-sufficiency in times of crisis, limited ambitions and the overriding importance of security. 
We may even question whether micro-entrepreneurialism is an adequate concept to define business practices motivated by necessity or by limited ambitions and whether, in using the concept of micro-entrepreneurialism, we are disregarding aspects of these practices that actually explain their existence, such as the subsistence ethos, the logic of security or their status as a way of life.

Given that the entrepreneurial spirit is not an innate characteristic of individuals, it results primarily from socialisation in environments with a strong entrepreneurial culture and implies a predisposition to tackle risks. Thus, it is easier for some rather than others to become entrepreneurs or set up their own business. In a very schematic way, it is the entrepreneurs who emerge from the popular economy - whether small agricultural producers, artisans, or poorly qualified workers - who are more distanced from the model that the economy intends to stimulate and support, precisely because they are more removed from those environments.

\subsection{The informal economy}

The informal economy represents a very favourable context for the development of small businesses and, more importantly, frequently corresponds to a period of consolidation in these businesses and to a strategy for the acquisition of entrepreneurial practices, leading later to the appearance of new activities in the formal sector of the economy.

The ILO defines these small business activities in the informal sector as goods and services production units whose primary aim is to create employment and income for the individuals involved. They are characterized by their low level of organisation and small scale, by little or no division between labour and capital as factors in production and by the fact that labour relations, where they exist, are based in most cases on casual work, kinship or personal and social relationships rather than on contracts with formal guarantees (OIT, 2006).

The negative aspects of these informal enterprises are well-known as they almost always constitute the better-known aspect of the phenomenon: their illegal nature (noncompliance with laws and regulations); their fraudulent nature (not contributing to government revenue by evading taxes); the fact that they practice unfair competition (competing unequally with formally established companies by avoiding the costs to which 
the latter are subjected); their potential criminal nature (some informal activities are criminal or illegal due to deliberate tax evasion).

However, informal activities, especially those on a small scale, are, for the most part, the only viable alternative for many people, representing an opportunity to earn an income for those who would otherwise be without any means of support. Rather than there being a kind of preference for the informal on the part of these individuals, it is evident that the informal economy is their most rational choice. For a person with no resources (not just financial, but also educational or social) the formal solution may be unfeasible. The uncertainty surrounding the success of a business makes investment in its formal constitution (authorisations, permits, taxes) prohibitive and highly risky. The tax and social security system and the labour laws are too restrictive or complex for such small-scale ventures. Moreover, if clients are not established, and given that the commercial climate is very often hostile to the setting up, growth and development of businesses, a temporary period of informality is seen as the best way of reducing the risk of not having customers and not mastering the market. Finally, the lack of material resources and ownership of property limits responsibility and prevents access to institutional credit, opening the door to fiduciary loans through primary social networks. Only these kinds of reasons can explain the insecurity and risk borne by informal entrepreneurs, such as tax fines, confiscation, penalties for economic crime, conviction for illegal practices, etc.

The restructuring of economies and labour markets has favoured the growth of informal activities, even in the more developed countries. There is an awareness nowadays on the part of governments that these activities play an important role in adapting to crisis situations, and therefore they are assessed less negatively. In some countries attempts are even made to offer some measure of protection to the informal sector without promoting it, specifically by offering greater incentives to informal businesses by reducing costs and increasing benefits in order to make them become, and remain, legal. Anyone wishing to set up a small business does not, in general, have access to marketing services, training in basic skills or technology transfer. One recent guideline involves making it easier to access these services and to help formalise companies. 


\subsection{The solidarity economy}

This category includes all forms of productive associations of workers which function as an alternative to unemployment, lack of income and marginalisation by the labour market. Falling into the area conventionally termed self-managed and cooperative, they are characterised by a set of principles that distinguish them from other forms of entrepreneurialism. These include self-management and cooperation in the workplace, participation, egalitarianism, self-sufficiency, human development and social responsibility (Gaiger, 2004: 11). Their philosophy is one of solidarity, not money or administrative power (Laville, 1994: 30).

The relationship between the solidarity-based and entrepreneurial aspects of these initiatives is explained by the need for new forms of association during a period marked by economic globalisation, the system of production chains and the crisis in waged work, and by a concern to evade massive unemployment and the social exclusion of workers which these factors have created, especially in the periphery of the world system. The entrepreneurial solution represents valuing both the advantages of cooperation, with the aim of improving living conditions, and the economic efficiency that results from a more appropriate and flexible use of resources, including labour.

The solidarity economy has developed greatly on a worldwide scale, even in developed countries within the European Union, such as France, Italy, Belgium and Spain. Its most distinctive characteristic is the plurality and newness of its forms: old and new forms of cooperatives and mutual societies, social and charitable organisations, social and solidaritybased companies, self-managed and alternative companies, collective initiatives for housing, local exchange systems, fair trade, solidarity-based financial institutions, production-consumption and other rural initiatives, employment integration companies and other kinds of initiatives within the solidarity economy run by the unemployed, women, ethnic minorities and other socially or economically disadvantaged people (ibid.).

As a rule, these initiatives mobilise a wide variety of resources and it is not unusual for them to benefit from significant support from public bodies, specifically the local authorities, precisely due to their capacity to find a solution for problems which conventional public policies cannot resolve. Their relationship with civil society and the state is therefore quite close, but is governed by the principles of solidarity and mutual recognition. 
In Portugal, collective and solidarity entrepreneurialism is still frail, despite the very rich experience of the second half of the 1970s which combined the effects of an acute crisis in the entrepreneurial sector (companies closing down, decapitalisation, abandonment) with the aspirations of workers for self-management. Currently, the autonomous association models for the production of goods and services are clearly subordinate to public bodies in terms of their strategy for promoting micro-entrepreneurialism, whilst at the same time lacking other forms of indispensible support in civil society that may help implement viable projects. Perhaps for this reason micro-enterprises in Portugal are predominantly initiatives set up by individual workers.

Whatever the case may be, the typical trajectories of the agents of the popular economy - in other words, their conversion to individual micro-entrepreneurs, informal workers or entrepreneurs, or solidarity-based entrepreneurs - do not impair their integration into the market, and can even be understood as a common strategy for escaping adverse integration into the capitalist sphere of the market.

These trajectories are therefore reversible in the sense that the actors may have to retreat in order to readjust their strategies. This frequently happens with those who become involved in businesses and see them fail due to a lack of conditions to meet the competitive standards of the market, resulting, for example, from an aversion to risk or a lack of availability to respond to the volume of work demanded by the market.

It is in these situations that the solution of the collective or solidarity-based production formulae becomes attractive. However, to achieve this, it is necessary for this option to be supported and stimulated by suitable policies, and for organisations to ensure that the use of market-dependent labour does not create hidden forms of proletarianisation.

Translated by Sheena Caldwell

Revised by Teresa Tavares

\section{References}

Academia Real das Sciencias de Lisboa (1789), Memórias Económicas. Vol. I. Lisbon: Oficina da ARSL.

Boulding, Kenneth; Tapan, Mukerjee (1972), Economic Imperialism: A Book of Readings. Ann Arbor: University of Michigan Press.

Cattani, A.; Laville, J.-L.; Gaiger, L.I.; Hespanha, P. (eds.) (2008), Dicionário Internacional da Outra Economia. Coimbra: Almedina.

Drucker, Peter (1985), Innovation \& Entrepreneurship: Practice and Principles. New York: Harper \& Row. 
Gaiger, Luiz I. (ed.) (2004), Sentidos e experiências da economia solidária no Brasil. Porto Alegre: Editora UFRGS.

Hespanha, Pedro (1990), "A propriedade multiforme. Um estudo sociológico sobre a evolução recente dos sistemas fundiários em Portugal," PhD dissertation, School of Economics, University of Coimbra.

Hespanha, Pedro (2000), "Mal-estar, conflitualidade e violência no mundo rural português. A crise dos anos 90," Revista Crítica de Ciências Sociais, 57/58, 25-51.

Hespanha, Pedro; Monteiro, Alcina; Ferreira, A. Cardoso; Rodrigues, Fernanda; Nunes, M. Helena; Hespanha, M. José; Madeira, Rosa; van den Hoven, Rudy; Portugal, Sílvia (1990), Entre o Estado e o Mercado. As fragilidades das Instituições de Proteç̧ão Social em Portugal. Coimbra: Ed. Quarteto.

Hespanha, Pedro; Damas, Ana; Ferreira, A. Cardoso; Nunes, M. Helena; Hespanha, M. José; Madeira, Rosa; van den Hoven, Rudy; Portugal, Sílvia (2002a), "Globalização insidiosa e excludente. Da incapacidade de organizar respostas à escala local", in Pedro Hespanha; Graça Carapinheiro (eds.), Risco social e incerteza: Pode o Estado social recuar mais? Porto: Afrontamento

Hespanha, Pedro; Portugal, Sílvia (2002b), A transformação da família e a regressão da sociedadeprovidência. Porto: Comissão de Coordenação da Região Norte.

Hespanha, Pedro; Caleiras, Jorge; Pessoa, Sandra; Pacheco, Vanda (2007), É o (des)emprego fonte de pobreza? Porto: REAPN.

Knight, Frank (1921), Risk, Uncertainty and Profit. Boston: Houghton Mifflin.

Laville, Jean-Louis (ed.) (1994), L'économie solidaire. Une perspective internationale. Paris: Desclée de Brouwer.

Lipton, Michael (1968), "The Theory of the Optimizing Peasant," Journal of Development Studies, 4, 327-351.

OIT (2006), A OIT e a economia informal. Lisbon: OIT.

Polanyi, Karl (1944), The Great Transformation: The Political and Economic Origins of Our Time. Boston: Beacon Press.

Popkin, Samuel (1979), The Rational Peasant. Berkeley: University of California Press.

Portela, José; Hespanha, Pedro; Nogueira, Cláudia; Teixeira, Sérgio; Baptista, Alberto (2008), Microempreendedorismo em Portugal. Lisboa: INSCOOP.

Reis, José (2007), Ensaios de Economia Impura. Coimbra: Almedina.

Say, Jean Baptist [1821] (1963), A Treatise on Political Economy. New Jersey: Augustus M. Kelly Publishers.

Schumpeter, Joseph (1934), Theory of Economic Development. New York: Oxford University Press.

Scott, James (1976), The Moral Economy of the Peasant. New Haven: Yale University Press.

Silbert, Albert (1978), Le Portugal méditerranéen à la fin de l'Ancien Régime, XVIIle-début du XIXe siècle. Lisbon: INIC.

Sousa, Liliana; Hespanha, Pedro; Rodrigues, Sofia; Grilo, Patrícia (2007), Famílias pobres: Desafios à intervenção social. Lisboa: Climepsi Editores.

Tepicht, Jerzy (1973), Marxisme et agriculture. Paris: Armand Colin. 